\title{
ASSESSMENT OF A NEW SELECTIVE MEDIUM FOR THE ISOLATION OF SALMONELLAE
}

\author{
JOAN R. DAVIES* \\ Bacteriological Laboratory (PHLS) County Hall, London, SEI
}

THE assessment of a new medium presents the microbiologist with a number of problems. He is likely to wish to compare such a medium with whatever medium he is currently using but whereas he is familiar with the performance of his own medium he has to learn the peculiarities of the experimental medium. Such a comparison may reflect not so much the inherent advantages of one medium over another but the expertise of the observer in making and using each of them. While one consideration in assessing a new medium is the efficiency with which pathogens can be isolated from clinical material, others of equal practical importance are the amount of work involved and the time taken to obtain the result of the investigation.

The proximity of the Bacteriological Laboratory (PHLS) at County Hall to the Westminster Medical School made it possible for us to compare deoxycholate-citrate agar (DCA) with the medium described by Shanson (1975) for the isolation of salmonellae other than S. typhi. DCA was the medium in routine use at the County Hall laboratory for the examination of faeces. For a time, Shanson's medium was made at Westminster and brought to County Hall ready for use. Later it was made at the County Hall laboratory. We had an opportunity, therefore, to become accustomed to the new medium and to ensure that a comparable product was made in the two laboratories.

The results of a comparison of Shanson's medium with DCA are reported here.

\section{MATERIALS AND METHODS}

Media. Shanson's medium was made as described (Shanson, 1975). Selenite broth was made by the method of Collins and Lyne (1970).

The preparation of DCA was based on Hynes' (1942) modification of Leifson's medium and was as follows. Constituents of base: peptone (Evans Medical Ltd, Speke, Liverpool) $5 \mathrm{~g}$; meat extract (Lab-Lemco paste L30, Oxoid Ltd, Southwark Bridge Road, London SE1 9HF) $5 \mathrm{~g}$; lactose (bacteriological) $10 \mathrm{~g}$; agar (New Zealand: Davis Gelatine Co., Upper Grove Street, Leamington Spa, Warwickshire) $11 \mathrm{~g}$; distilled water 1 litre. Preparation of base: agar and meat extract were dissolved in water, and peptone and lactose were added with thorough mixing. The $p \mathrm{H}$ of the medium was adjusted to 8.4 with $\mathrm{N} \mathrm{NaOH}$ and it was distributed in 0.5 -litre volumes. Sterilisation was at $115^{\circ} \mathrm{C}$ for $10 \mathrm{~min}$, with storage at room temperature. Constituents of solution $\mathrm{A}$ : trisodium citrate, $\mathrm{Na}_{3} \mathrm{C}_{6} \mathrm{H}_{5} \mathrm{O}_{7} .2 \mathrm{H}_{2} \mathrm{O}$ (Analar, BDH Chemicals, Poole, Dorset), $17 \mathrm{~g}$; sodium thiosulphate, $\mathrm{Na}_{2} \mathrm{~S}_{2} \mathrm{O}_{3} .5 \mathrm{H}_{2} \mathrm{O}$ (Analar, Hopkin and Williams, P.O. Box 1, Romford, RM1 1HA), $17 \mathrm{~g}$; ferric citrate scales (BDH) $2 \mathrm{~g}$; sterile distilled water $100 \mathrm{ml}$. Preparation of solution A: the constituents were dissolved with minimum heating. The solution was distributed in 25 -ml volumes in screw-cap " universal " bottles and stored at room temperature. Preparation of solution $B$ : sodium deoxycholate (Ward, Blenkinsop and Co., Empire Way, Wembley, Middlesex), 5-10 g, was dissolved in $100 \mathrm{ml}$ of sterile distilled water and $\mathrm{NaOH}$ added as required. The solution was distributed in $25-\mathrm{ml}$ volumes and stored at room temperature. Each batch of deoxycholate was assessed before purchase and standardised to give acceptable results in experiments on

Received 30 May 1973; accepted 28 Jan. 1974.

* Present address: Public Health Laboratory, St Luke's Hospital, Guildford, Surrey.

J. MED. MICROBIOL. - VOL. 8 (1975) 
efficiency of plating and in routine use. Particular attention was paid to colonial appearance and suitability of colonies for slide agglutination. For each batch, an amount of $\mathrm{N} \mathrm{NaOH}$ was required such that a final $p \mathrm{H}$ of 7.0 was produced in a mixture of equal volumes of solutions A and B. This amount was determined by experiment and the complete medium was tested for suitability. Preparation of the complete medium: 0.5 litre of base was melted, and to it were added $25-\mathrm{ml}$ amounts each of solutions $A$ and $B$. The $p H$ was adjusted to $7 \cdot 3$ and $1.0 \mathrm{ml}$ of $1 \%$ aqueous neutral red added. The medium was mixed well and plates were poured immediately.

Specimens. Specimens of faeces from patients with acute diarrhoea, from contacts and from convalescents, were examined in parallel on DCA and Shanson's medium, both by direct plating and after enrichment in selenite broth. The plates and broth were incubated overnight at $35^{\circ} \mathrm{C}$. The specimens were unselected, but those that yielded shigellae or $S$. typhi have been excluded from the analysis.

\section{RESULTS AND DISCUSSION}

\section{Non-lactose-fermenters (NLFs)}

It will be seen (the table) that the two media were of similar efficiency for the isolation of salmonellae; 10 serotypes were represented in this series. Shanson's medium was much more selective, in that the growth of many non-pathogenic NLFs was suppressed. This was a real advantage, particularly in the examination of specimens that contain large numbers of Proteus and small numbers of a salmonella, and resulted in a great reduction in the amount of bench work required to produce a result. Most workers examine the plates, and screen colonially typical NLFs by biochemical or serological tests; over one-third of these specimens, when plated on DCA, required manipulations of this sort. On Shanson's medium far fewer specimens yielded NLFs and a high proportion of these were salmonellae.

Although it was sometimes possible to obtain a suspension suitable for slide agglutination from colonies on Shanson's medium this was not invariably so. Some colonies were difficult to emulsify, others agglutinated in saline. It was found that the most convenient procedure was to subculture all NLFs that appeared on Shanson's medium on to MacConkey's agar, and at the same time to inoculate a tube of glucose broth. After $4 \mathrm{~h}$ in a water bath at $37^{\circ} \mathrm{C}$, the growth in broth was formolised and tested with Salmonella $\mathbf{H}$ agglutinating sera in a water-bath at $50^{\circ} \mathrm{C}$. In this way a presumptive positive result could be obtained on the day on which growth was first observed on solid medium. The identification was completed on the following days by further examination of the subculture on MacConkey's agar. Some of the colonies recorded initially as NLFs on Shanson's medium were shown on subculture to be lactose fermenters.

TABLE

Results of examining 340 specimens of faeces on deoxycholate-citrate agar (DCA) and Shanson's (1975) medium

\begin{tabular}{|c|c|c|c|c|}
\hline \multirow{3}{*}{ Kind of growth } & \multicolumn{4}{|c|}{ Number of specimens that gave the kind of growth indicated } \\
\hline & \multicolumn{2}{|c|}{ by direct plating on to } & \multicolumn{2}{|c|}{$\begin{array}{l}\text { by subculture from selenite } \\
\text { broth on to }\end{array}$} \\
\hline & DCA & $\begin{array}{l}\text { Shanson's } \\
\text { medium }\end{array}$ & DCA & $\begin{array}{l}\text { Shanson's } \\
\text { medium }\end{array}$ \\
\hline \multirow{2}{*}{$\begin{array}{l}\text { No non-lactose-fermenters } \\
\text { Non-pathogenic non-lactose- } \\
\text { fermenters only } \\
\text { Salmonella }\end{array}$} & 211 & 309 & 191 & 289 \\
\hline & $\begin{array}{r}120 \\
9\end{array}$ & $\begin{array}{r}22 \\
9\end{array}$ & $\begin{array}{r}123 \\
26\end{array}$ & $\begin{array}{l}27 \\
24\end{array}$ \\
\hline
\end{tabular}




\section{Lactose fermenters}

Both media inhibited the growth of lactose fermenters; on direct plating there was no difference between them. About a quarter of the subcultures from selenite broth showed a heavier growth of lactose fermenters when plated on DCA than on Shanson's medium. This was generally due to the growth of Klebsiella aerogenes.

\section{Standardisation of media}

The DCA with which Shanson's medium was compared was controlled in two respects. The deoxycholate had been batch-tested for suitability and the $p \mathrm{H}$ was carefully adjusted. It was a medium that had been in routine use in the laboratory for many years. It would be absurd to pretend that we were not prejudiced in favour of DCA. Shanson's medium needs to be prepared with care and with attention to the limitations on storage times and temperatures that are specified. A batch should be tested with control strains whose behaviour on the medium is known.

Shanson's medium provides a useful addition to the plating media for the investigation of suspected salmonella infections. Strains of salmonellae produce a typical colonial appearance and very few other organisms grow. The medium would be particularly useful if large numbers of specimens were to be examined.

\section{SUMMARY}

Shanson's medium, a MacConkey-type agar containing added inhibitors, was compared with deoxycholate-citrate agar for the examination of faeces. The isolation rate of salmonellae on the two media was similar, but Shanson's medium was the more selective; this meant that the amount of work required to produce a result was reduced.

Dr David Shanson stimulated our interest and showed us how to make his medium. I am grateful for the expertise of Mr J. Leavy, who made the media, and to Mr W. N. Farrant who used them.

\section{REFERENCES}

Collins, C. H. AND Lyne, P. M. 1970. Microbiological methods, 3rd ed., London, p. 126. HYNES, M. 1942. The isolation of intestinal pathogens by selective media. J. Path. Bact., 54, 193.

Shanson, D. C. 1975. A new selective medium for the isolation of salmonellae other than Salmonella typhi. J. med. Microbiol., 8, 357. 